\title{
Memorias de la escuela pública
}

\author{
Jhon Henry Orozco Tabares
}

Martínez Boom, Alberto. (2010) Memorias de la Escuela Pública. Expedientes y planes de escuela en Colombia y Venezuela: 1774-1821.

Alguien podría imaginar la existencia de una mitología de la escuela y del maestro público entre nosotros. Una suerte de imagen remota perdida en el tiempo como si lo antiguo pudiera confundirse con lo insensato. Afortunadamente, la investigación arqueológica tiene el mérito de separarnos de la idealización y de sus sombras para acercarnos a los momentos de gestación de los acontecimientos. Si la memoria es vasta como lo pensaba Borges refiriéndose a la biblioteca, el esfuerzo de selección minuciosa, acumulación detallada y ordenación conceptual que el profesor Alberto Martínez Boom logra y propone con este libro, nos permite apropiar una parte definitiva del Archivo Pedagógico de la Colonia.

La edición de treinta fuentes primarias referidas a planes y expedientes de escuela en los territorios correspondientes al Nuevo Reino de Granada y la Capitanía de Venezuela, es una apuesta que salva estos expedientes de sus puertos lejanos. Hay tanto olvido del archivo en la investigación actual, que apenas si entendemos la función de lo remoto y de sus grafías como elementos diagnósticos del presente.

Advierte el autor al inicio de su trabajo que asistimos a una compilación que sintetiza 30 años continuos de relación con el archivo y que esta tarea, cuya alborada data de 1978, se inscribe en las dinámicas de un trayecto investigativo adelantado por el Grupo de Historia de la Práctica Pedagógica en Colombia, del que podemos desprender una lección fundamental: "En muchos de los trabajos sobre educación en América Latina, los procesos que muestran el surgimiento de la escuela aparecen diluidos en la narración de los hechos económicos y políticos, desdibujados en la ilusión de una unidad y una plétora incontrovertibles [...] Al tomar distancia de estas etiquetas totalizantes, consideramos que la historia de las prácticas pedagógicas tiene su propia especificidad y unos periodos que no necesariamente se compaginan 


\section{Evaluación}

12. El comité de redacción procederá a la selección de los trabajos de acuerdo con los criterios formales y de contenido de esta publicación.

13. El material seleccionado se remitirá a evaluación de pares académicos y posteriormente, se someterá a arbitraje para determinar si será publicado y la fecha de publicación.

14. Una vez definida la publicación o no de un texto, se le informará al autor. Los autores de los textos aprobados, deberán autorizar por escrito a la Universidad Pedagógica Nacional para su publicación. 